TECHNICAL TRANSACTIONS 7/2017

CZASOPISMO TECHNICZNE 7/2017

ENVIRONMENTAL ENGINEERING

DOI: $10.4467 / 2353737$ XCT.17.112.6653

\author{
Monika Szlapa (monika.szlapa@iigw.pk.edu.pl) \\ Paweł S. Hachaj \\ Institute of Water Engineering and Water Management, Faculty of Environmental \\ Engineering, Cracow University of Technology
}

\title{
THE IMPACT OF PROCESSES OF SEDIMENT TRANSPORT ON STORAGE
}

\section{RESERVOIR FUNCTIONS}

WPEYW PROCESÓW TRANSPORTU SEDYMENTU NA FUNKCJONOWANIE

ZBIORNIKÓW RETENCYJNYCH

\begin{abstract}
Maintaining the good condition of water reservoirs is always one of the main tasks of water management. This is especially vital when the reservoir serves as a water supply and/or a facility for recreational activities. No only what goes into the lake but also everything that is stored within the area needs to be considered. In a case of dam reservoirs, one of the important issues is the transport and storage of sediment. This paper focuses on the sediment which is characteristic of the Dobczyce Reservoir and considers situations which may potentially generate problems from the point of view of maintaining good condition of the water body.

Keywords: sediment transport, retention reservoir, numerical modelling, hydrodynamic, water quality
\end{abstract}

\section{Streszczenie}

Utrzymanie dobrego stanu zbiorników wodnych jest zawsze jednym z najważniejszych zadań gospodarki wodnej. Jest tak zwłaszcza, gdy wśród funkcji rezerwuaru znajduje się zaopatrzenie w wodę i/lub rekreacja. Zjednej strony należy zwrócić uwagę na materię dostarczaną do zbiornika, z drugiejzaś na to, co w tej przestrzeni jest deponowane. Ta praca skupia się na charakterystyce osadów zbiornika Dobczyckiego i rozważeniu scenariuszy mogących generować sytuacje problemowe dla utrzymania dobrego stanu zbiornika wodnego.

Słowa kluczowe: transport sedymentu, zbiornik retencyjny, modelowanie numeryczne, hydrodynamika, jakość wody 


\section{Introduction}

Building storage reservoirs by blocking rivers with dams is a method of water management that civilisations have used since ancient times and is still used today. These reservoirs may have many vital functions that meet a lot of needs. The most common functions nowadays are: water supply; power generation; flood/drought protection; recreation. The local environment changes as a result of human impact; thus, it needs continuous monitoring and treatment. In the case of a reservoir which is a source of potable water, maintaining the water quality is the primary task. There are several important points that need to be considered, these are not limited to the kind of contamination that may enter the water source but also includes everything that is already present within the area. In the case of a dam reservoir, the dam itself is a physical obstacle for flowing water and it makes the river current slow down within the lake. In such a case, some important sediment transport phenomena occur; these are most visible in the backwater areas resulting in sediment accumulation.

With regard to sediment transport phenomena, storage reservoirs are primarily considered to be accumulation zones within the course of rivers (for a good overview, see [14]). In such cases, relatively simple and robust $1 \mathrm{D}$ models may be used; however, when it comes to sediment transport within reservoirs, there is a need for multidimensional models. The significant increase of computing power that has occurred in recent years has made such calculations feasible to perform within a reasonable timeframe. A review of models in use can be found in [17], while a comprehensive approach to applying mathematical methods of sediment movement in an around reservoirs is presented in [24].

This paper focuses on the problem of sediment transport and storage in a dam reservoir using the example of the Dobczyce Lake.

\section{Research area}

The area of research is the Dobczyce reservoir located in the south of Poland in the Lesser Poland voivodeship (Fig. 1). The lake was created by building a dam on the $60^{\text {th }}$ kilometre of the Raba river - the Raba is one of the tributaries of the Vistula. The parameters of the Dobczyce reservoir are presented in Table 1, the shape of the reservoir and its principal objects are shown in Fig. 2.

Knowledge regarding the propagation of pollution in this reservoir is as important as the main function of the Dobczyce Lake itself - the lake is the primary water source for the nearby city of Cracow. Therefore, the issue of water quality is among the top priorities and currently, the whole lake is a protected area. However, allowing limited recreation activities in some parts of the lake has been discussed many times in the past. It is likely that some kind of recreation will be allowed there in the future. Thus, the potential sources of pollution and contamination propagation should be inspected, both for the sake of keeping the recreation areas clean and to minimise the impact of these areas on the water supply system. 
Table 1. Reservoir parameters $[7,19,22]$

\begin{tabular}{|c|cc|}
\hline Capacity $\left[\mathbf{m l n ~}^{3}\right]$ & $\min$ & 23.23 \\
& $\max$ & 137.95 \\
\hline \multirow{2}{*}{ Surface $\left[\mathbf{k m}^{2}\right]$} & $\min$ & 3.35 \\
& $\max$ & 10.65 \\
\hline \multirow{2}{*}{ Water discharge $\left[\mathrm{m}^{3} / \mathbf{s}\right]$} & $\min$ & 1.8 \\
& most probable & 2.03 \\
& yearly average & 10.6 \\
& mean $\left(Q_{\text {so\% }}\right)$ & 200 \\
& highest observed & 1150 \\
\hline \multirow{2}{*}{ Water surface elevation $[\mathbf{m}$ a.s.l. $]$} & $\min$ & 256.7 \\
& $\max$ & 272.6 \\
\hline Depth $[\mathbf{m}]$ & $\max$ & 30 \\
\hline Catchment area $\left[\mathbf{k m}^{2}\right]$ & & 768 \\
\hline
\end{tabular}

The subject of the propagation of pollutants dissolved in storage reservoir water has been considered in previous articles $[8,9,10]$. In this paper, the authors focus on the sedimentbased constituents including those entering the reservoir as well as those already present. Preliminary studies on both the direct and the indirect impact of sediment gathering and transport on the condition of the reservoir are analysed.

The sediment transport phenomena are most intensive and most visible in the backwater region. This is the zone where the borders between the river and the lake are blurry - in fact, they change along with the water surface elevation in the reservoir. In this area, the velocity of water decreases and its potential for carrying rubble and suspended particles also decreases. Conditions like these are favourable for the settling of sedimentary grains on the bed of the lake.

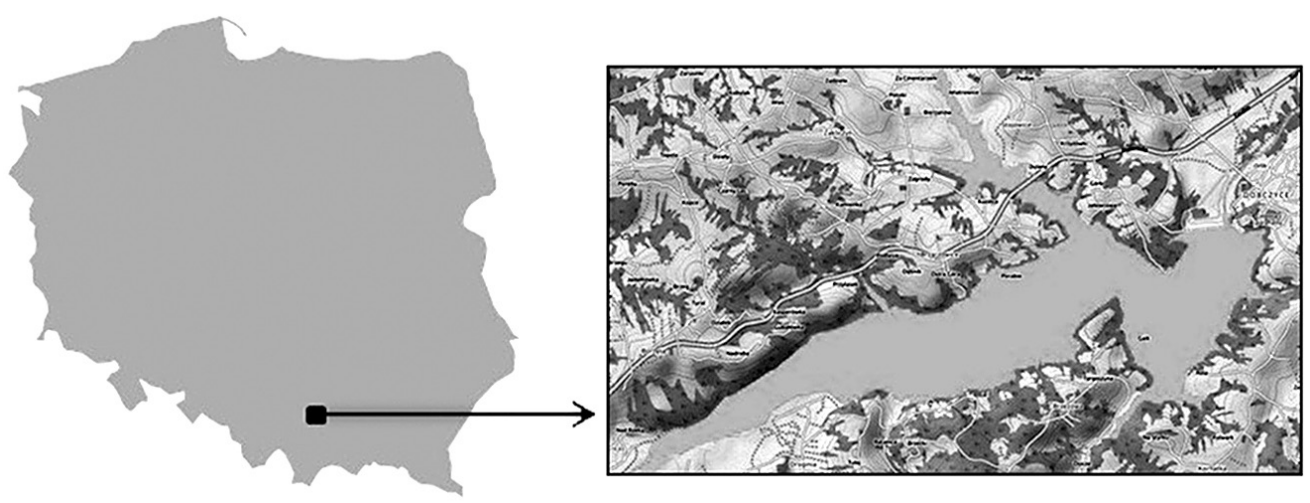

Fig. 1. Geographical location of the Dobczyce Lake and its shape 


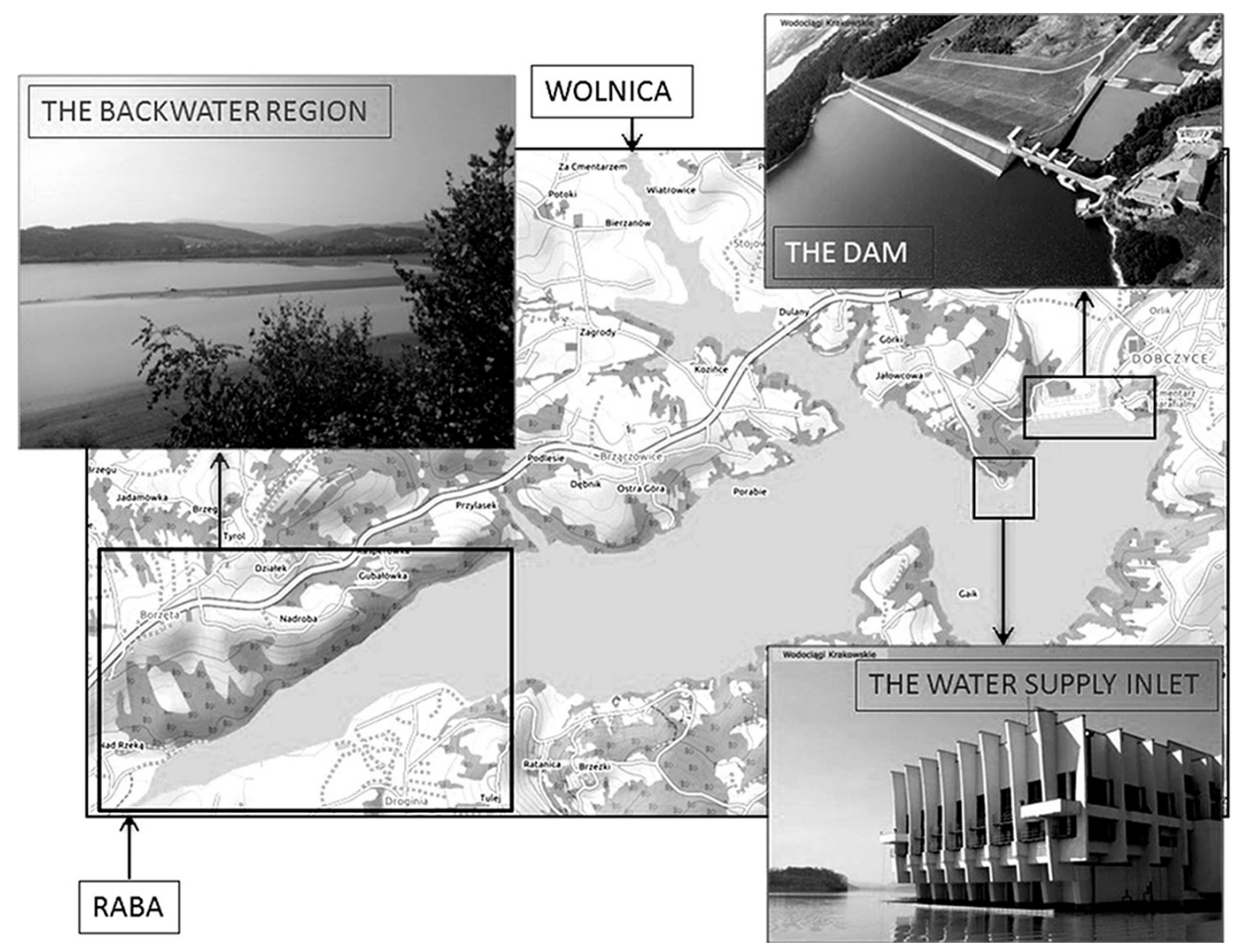

Fig. 2. Location of the strategic areas of the Dobczyce Reservoir (Photos: MPWiK Kraków)

\section{Backwater region analysis}

In considering the direct impact of the sediment on the lake, it is worth to following the transformation of this area through the years. The aerial photos presented below (Figs. $3 \& 4$ ) show the seventeen-year history of changes to the backwater environment as sediments have built up to form land.

Figure 3 depicts the process of transformation of the estuary area from 1997 to 2014 . The main process that occurs is the deposition of material transported by the river - this is marked by solid black lines on the subsequent photos. The only region where deepening of the water is visible is the area where the river material was artificially removed (region marked with a white line on the 2009 part of Fig. 3). Even following the large flood that occurred in this area in 2010, the effect of the deposition process is more significant than the flushing out of material from this area The high discharge that time made new river channels cut within the newly created land (in the area marked by the long white ellipse in the photo from 2010). However, the total area of dry regions simultaneously increased after that flood. Some of the previously gathered material was certainly flushed out to deeper areas of the lake that time, although this effect was less significant than the deposition process. The marked area visible in Fig. 4 is about 1.5km long area of land and wetland with plants such as grass, small trees and 
shrubs. The annual average amount of sediment gathered in the reservoir is about $185,000 \mathrm{~m}^{3}$ - this value is close to that which was predicted when the reservoir was designed [3].

As shown, most of the sediment is deposited in the shallow western region of the reservoir, close to the inflow of the Raba river. To get more information about the properties of the material deposited in the backwater area, and to obtain some knowledge about the intensity of the process in this region, a local investigation and a laboratory analysis have been conducted. The initial in-situ research included local observations of the actual state of the reservoir with regard to siltation, the choosing of places for sediment sampling and measurements as well as the macroscopic classification of material deposited in the backwater region; preliminary observations indicated the presence of fine and very fine (clay-like) material there.

All local measurements were performed in the moderately dry season when the water surface in the reservoir was low, thus uncovering large areas of the backwater region of the lake. The water surface elevation was approximately $267 \mathrm{~m}$ a.s.l. - this is $3 \mathrm{~m}$ lower than the average state desired in standard hydrometeorologic conditions. The exposed area provided evidence that intensive deposition processes occurred there. The terrain there is flat - this results in long and broad shallows when the water level is high enough to cover it.

In the backwater area, the samples was collected at five points on both the southern and northern sides of the reservoir (Fig. 5). The sampling collection indicated that the thickness of the sedimentary layer is variable and can even exceed $3 \mathrm{~m}$ in depth. The accumulated material can be classified as 'fine fractions' as defined in [18]. The sediment was well hydrated and organic matter was visibly present.

The laboratory research included sieve and aerometric analyses as well as identification of the contribution of mineral and organic fractions in the samples. Table 2 presents the average grain size at each sampling point at specified depths. The research confirmed the macroscopic in-situ observations - the material deposited within the research area could be classified as clay or clay silt. The proportion of organic matter in the dry mass was between $3.75 \%$ and $6.75 \%$. This proportion is relatively small but it should be noted that organic matter contributes much towards the total volume when it is hydrated. It was observed that the average grain size was larger for locations close to the main current (northern bank, locations 4 and 5) than in the regions far from it. There seems to be no direct correlation between the grain size and the depth level of the sample; this appears to be random. The most probable explanation for this is that the pattern of the main current was different for previous episodes of high discharge (i.e. floods) and this resulted in the occasional depositing of coarser sediment in seemingly random places. Traces of stronger current appear at measuring point 1 , starting at a depth of $1.4 \mathrm{~m}$. For point 2 - further inside the reservoir - bigger grains start to appear at a depth of approximately $1 \mathrm{~m}$. It is noteworthy that for the third measuring point (which is placed on the newly created land), the coarse fraction is scarce up to at least $3.2 \mathrm{~m}$ (which was the depth limit of the drilling performed there).

There is no evident dependence between the percentage of organic matter and either the position or depth of the sampling with the exception that in the upper layers of sites 4 and 5 (that are presently located in the strong current zone), the organic fraction is lower than anywhere else (3.75\%-4.5\% versus $5.15 \%-6.75 \%$ elsewhere). 

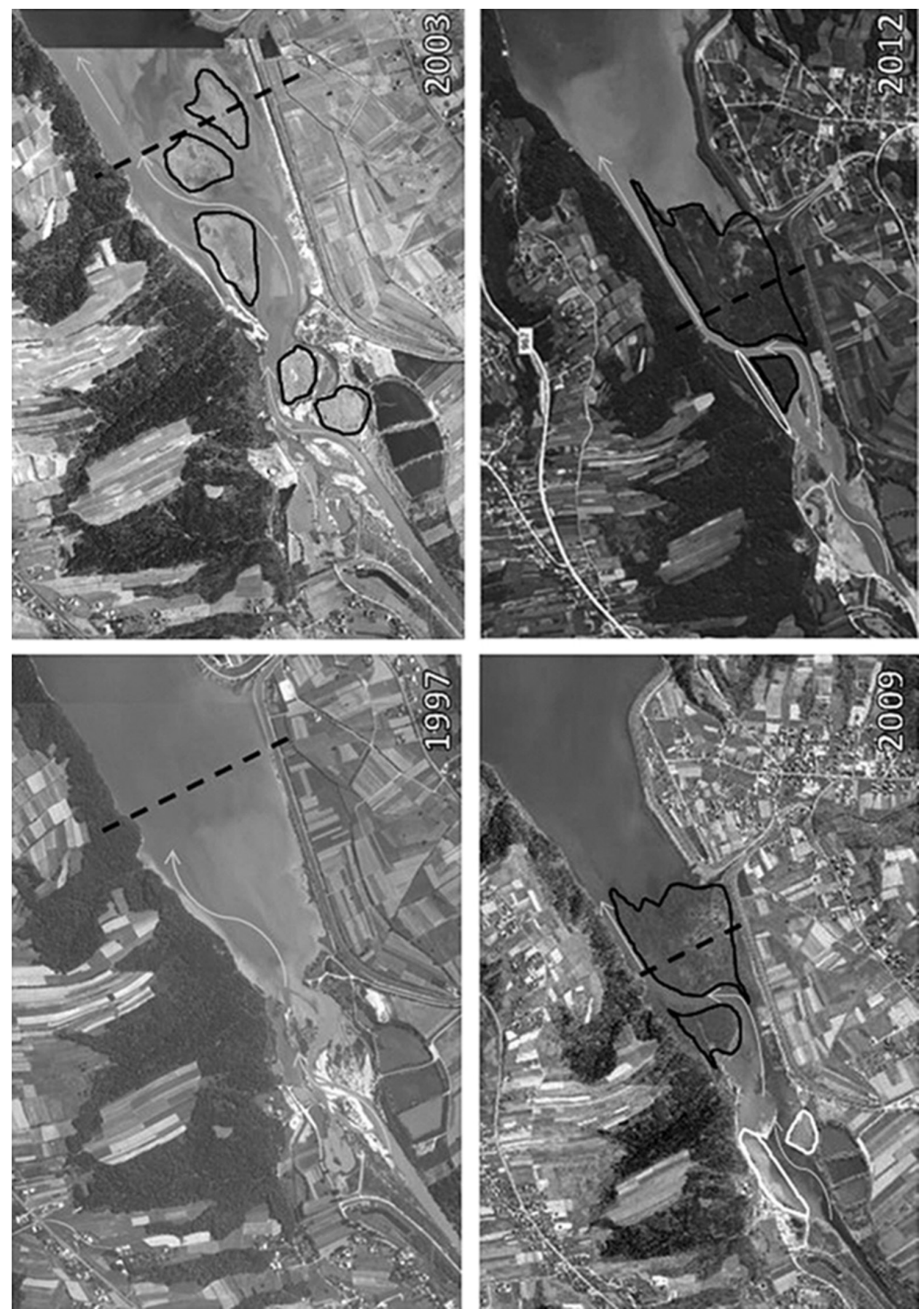

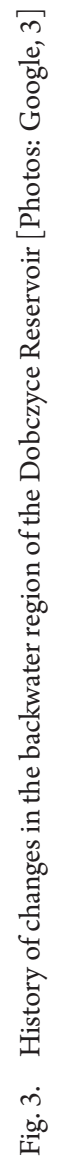

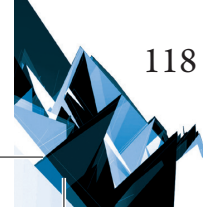




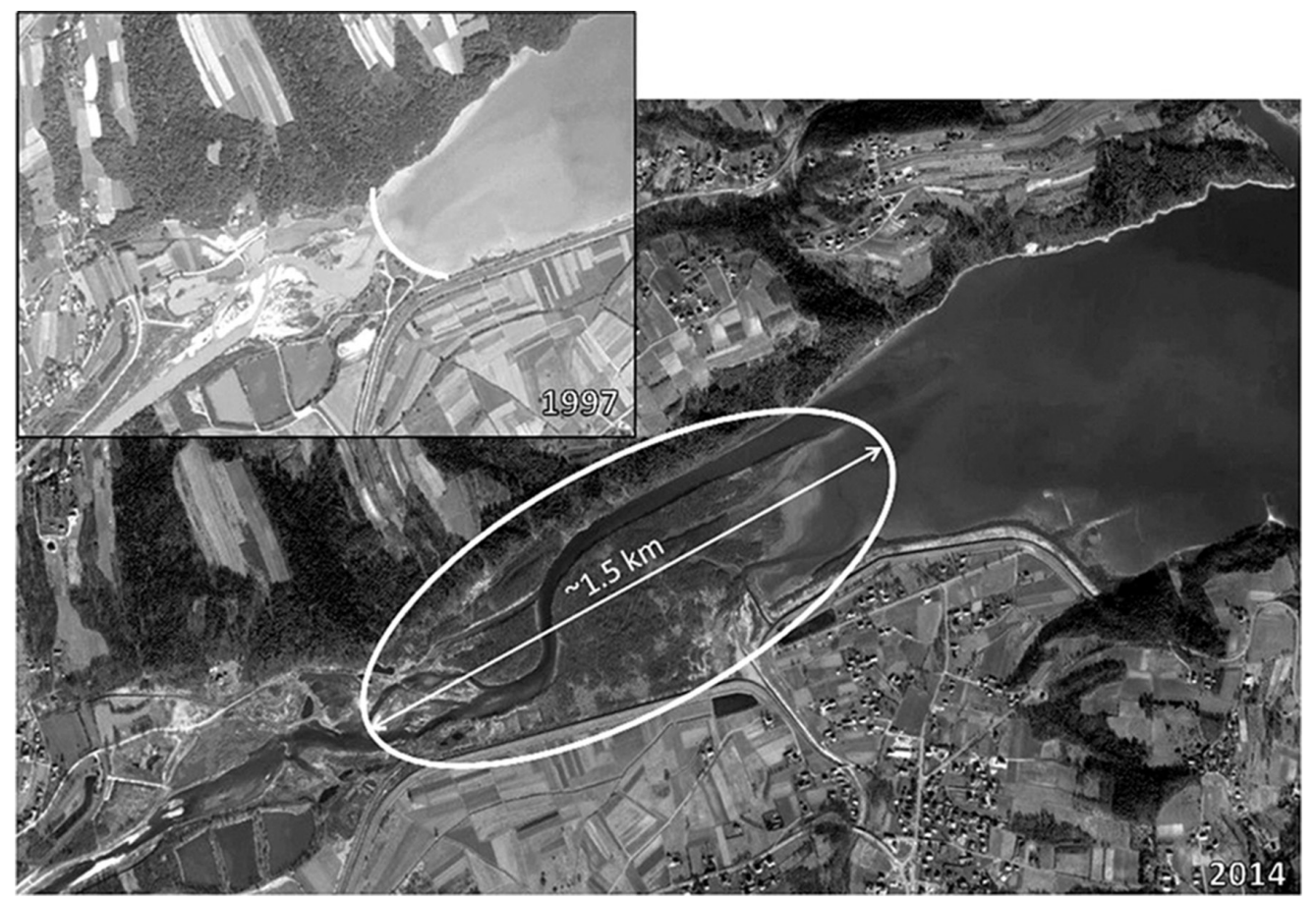

Fig. 4. Siltation of the backwater region 1997-2014

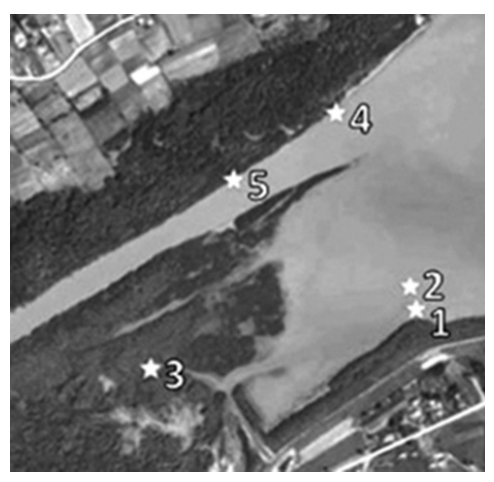

Fig. 5. Locations of sampling

Table 2. Grain diameter at various depths in the sampled locations

\begin{tabular}{|c|c|c|c|c|c|}
\hline \multicolumn{7}{|c|}{ Average grain diameter $\mathrm{d}_{50}[\mathrm{~mm}]$} \\
\hline $\mathbf{h}[\mathbf{m}] \backslash \mathbf{p t .}$ & $\mathbf{1}$ & $\mathbf{2}$ & $\mathbf{3}$ & $\mathbf{4}$ & $\mathbf{5}$ \\
\hline $\mathbf{0 . 0 - 0 . 2}$ & 0.016 & 0.014 & 0.016 & 0.030 & 0.020 \\
\hline $\mathbf{0 . 2 - 0 . 4}$ & 0.014 & 0.019 & 0.018 & 0.130 & 0.034 \\
\hline $\mathbf{0 . 4 - 0 . 6}$ & 0.018 & 0.016 & - & - & 0.050 \\
\hline $\mathbf{0 . 6 - 0 . 8}$ & 0.026 & - & 0.014 & 0.026 & - \\
\hline $\mathbf{0 . 8 - 1 . 0}$ & 0.014 & 0.024 & - & 0.020 & 0.026 \\
\hline $\mathbf{1 . 0 - 1 . 2}$ & 0.016 & 0.034 & 0.015 & - & 0.017 \\
\hline $\mathbf{1 . 2 - 1 . 4}$ & 0.017 & 0.040 & - & 0.018 & 0.019 \\
\hline $\mathbf{1 . 4 - 1 . 6}$ & 0.036 & 0.029 & 0.014 & 0.024 & 0.024 \\
\hline $\mathbf{m i n}$ & 0.014 & 0.014 & 0.014 & 0.018 & 0.017 \\
\hline max & 0.036 & 0.040 & 0.018 & 0.130 & 0.050 \\
\hline
\end{tabular}

\section{Numerical modelling of the processes of the sediment transport}

To model the sediment transport processes, the PTM (Particle Tracking Model) [16] was used. This model was created by US Army Corps of Engineers [23] and is one of the simulation tools integrated within the SMS (surface water modeling solution) [1]. 
The basic procedure of the PTM is as follows: a region (geometry) with bathymetric and sediment data is defined; flow (and wave data if applicable) are entered into to the model; virtual particles are released into the flow. The geometry data is usually prepared within the SMS environment. The flow data may originate from various hydrodynamic models that create their output as planar velocity fields (with the vertical velocity component neglected) - these are then interpolated with the geometry mesh (grid) used by the PTM.

The computations model the behaviour of the particles over the course of time (entrainment, advection, diffusion, settling, deposition, burial, etc.). Two types of calculations are performed at each time-step of PTM. Eulerian (mesh-based) calculations are required to determine the local characteristics of the environment, and Lagrangian (particle-based) calculations are required to determine the behaviour of each tracked particle.

Within the Eulerian calculations, the PTM requires potential transport rates to determine the likelihood of the burial of a sediment particle once deposited, as well as to get a particle from the bed moving again. This can be done using either one of two techniques, namely Soulsbyvan Rijn [21] and van Rijn [25]. The authors of the model recommend the first of these as it is significantly faster. The Soulsby-van Rijn total load sediment transport equation [21] is:

$$
q_{t}=A_{s} \bar{U}\left(\left(\bar{U}^{2}+\frac{0.018}{C_{D}} \bar{U}_{w}^{2}\right)^{1 / 2}-U_{c r}\right)^{2.4}
$$

where:

$q_{t}$ - total transport rate;

$A_{s}$ - coefficient dependant on grain size;

$\vec{U}$ - depth averaged planar velocity;

$\bar{U}_{w}$ - average wave orbital velocity;

$C_{D}$ - wave drag coefficient;

$U_{c r}$ - critical (threshold) velocity for motion/suspension regimes $U$.

The coefficient $A_{s}=A_{s b}+A_{s s}$, with the terms for bedload and suspended load respectively, is given by:

$$
\begin{aligned}
& A_{s b}=\frac{0.005 h\left(D_{50} / h\right)^{2.4}}{\left(g(s-1) D_{50}\right)^{1.2}} \\
& A_{s s}=\frac{0.0012 D_{50} D_{g r}^{-0.6}}{\left(g(s-1) D_{50}\right)^{1.2}}
\end{aligned}
$$

where:

$h$ - local depth;

$D_{50}-$ median surficial sediment grain size; 
$D_{g r}$ - dimensionless grain size;

$g$ - gravitational acceleration;

$s$ - relative local density.

The critical velocity is calculated separately for particles considered to be 'large' or 'small':

$$
U_{c r}= \begin{cases}0.19 D_{50}^{0.1} \log _{10}\left(\frac{4 h}{D_{90}}\right) & \text { for } D_{50}<0.5 \mathrm{~mm} \\ 8.5 D_{50}^{0.6} \log _{10}\left(\frac{4 h}{D_{90}}\right) & \text { for } D_{50} \geq 0.5 \mathrm{~mm}\end{cases}
$$

where:

$D_{50}, D_{90}$ - appropriate percentiles of surficial grain size.

It should be noted that the wave term in the sediment transport equation can be omitted for calculations relating to lakes and rivers; thus, it was not used in the modelling described in this article $\left(\bar{U}_{w}=0\right)$; therefore, there was no need to find the value of the wave drag coefficient $C_{D}$.

For the Lagrangian calculations regarding positions of the simulated sediment particles, the PTM uses a second-order, predictor-corrector technique to identify particle position at time $t+d t$ for each of the three orthogonal dimensions $x, y$, and $z$.

For example, for the dimension $x$, the first stage of the procedure uses information relating to the particle's present position and time to predict the particle's position half a time-step into the future, $x^{\prime}$, as:

where:

$$
x^{\prime}=x_{n}+0.5\left(u_{A}+u_{D}\right) d t
$$

$x^{\prime}$ - new position along the $x$ axis;

$x_{n}-x$ position in the previous, $n$-th, step;

$u_{A}$ - advection velocity in the $x$ dimension;

$u_{D}$ - diffusion velocity in the $x$ dimension.

The second stage of the procedure scheme uses information regarding velocity components from this location over a full time-step:

$$
x_{n+1}=x_{n}+\left(u_{A}^{\prime}+u_{D}^{\prime}\right) d t
$$

where the velocity components $u_{A}$ and $u_{D}$ are determined in the middle point (calculated above).

For the advection velocity, the local horizontal velocity at the elevation of the particle, $u^{*}$, is taken (according to vertical velocity distribution) - this may then be adjusted to account for bed-interaction. 
For the diffusion velocity, in the absence of information on eddy diffusivity from the hydrodynamic model, the PTM estimates lateral diffusivity itself. As presented in [7] and as applied in [20] amongst others, the turbulent diffusion coefficient, $E_{t}$, is estimated to be:

$$
E_{t}=K_{E_{t}} h u_{*}
$$

where the empirical coefficient $K_{E_{t}}$ relates the turbulent diffusion to the local shear velocity and water depth. Typically, $K_{E_{t}}$ ranges from 0.15 to 0.6 .

The diffusion velocity for the given time step is then calculated as a part of a random walk process:

$$
u_{D}=\Psi \sqrt{\frac{6 E_{t}}{d t}}
$$

where $\Psi$ is a random number between -1 and 1 with the uniform distribution.

\section{Application of the model and its results}

There have been a number of simulations of water dynamics performed for the Dobczyce Lake so far - these simulations used models contained in the SMS package, e.g. FESWMS [6], RMA [4, 15]. On the basis of findings from previous studies $[8,11,12,13,26]$ flow simulations were performed using the $\mathrm{AdH}$ model [2]. An AdH simulated velocity field was chosen as the hydrodynamic background for the PTM models runs. The simulation process was carried out for the hydrodynamic conditions corresponding to the annual average flow $\left(Q_{a v}=10.6 \mathrm{~m}^{3} / \mathrm{s}\right)$ as a representative 'low discharge' and a flow with a probability level of $50 \%$ $\left(Q_{50 \%}=200 \mathrm{~m}^{3} / \mathrm{s}\right)$ as the representative 'high discharge'. The water surface level was set as the average (269.6 m a.s.l.) and high (272.6 m a.s.l.) values for the reservoir. A 'stationary state' assumption (inflow=outflow) was made. Incoming and outgoing discharge were both split - the inflow between the Raba and Wolnica rivers; the outflow between the dam facilities and water supply inlet - this is close to the actual conditions in the reservoir. Wave impact was neglected as it has little impact on the water dynamics. Bank abrasion was also considered as a negligible source of sediment compared to the load carried by the Raba river.

The modelling process included tracking the behaviour of the sediment sample with the parameters of diameter distribution, specific gravity, loading time and location remaining the same for all the simulation runs. The physical parameters were as close as possible to the measured ones. In the simulations, a localised source of particles ('point source') was used with a one-metre horizontal and vertical dispersion radius. This was located in the main current of the Raba, where the river enters the lake in order to mimic material entering the backwater region from the main river inflow. The source was active for one hour, the simulation was then carried out over subsequent days; as a result, the evolution of the material carried into the lake over the course of one hour was observed. 


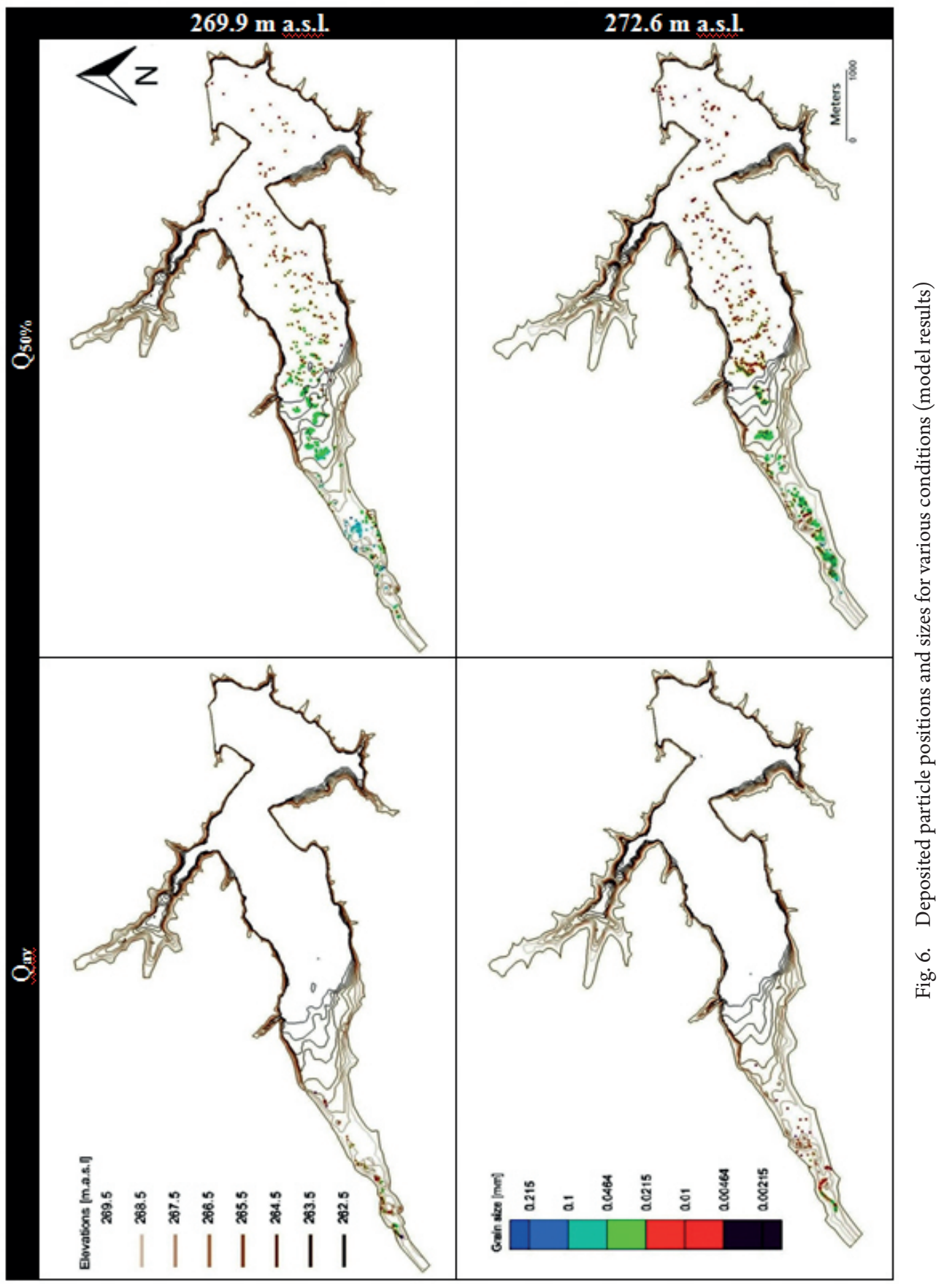


The simulations were run until all the modelled sediment particles were either settled on the reservoir bed or moved all the way to the lake outflow; the latter accounted for only a small proportion of the sediment and only applied in the case of high discharge conditions and for the smallest particles $(d<0.01 \mathrm{~mm})$. Figure 6 depicts the spatial distribution of the particles after seven days of simulation. Coloured dots represent deposited particles of various grain sizes. It can be seen that for $Q_{a v}$, almost all the grains are deposited in the backwater region of the reservoir. For the higher discharge value, the sediment particles, especially the smaller particles, are often carried further down the reservoir.

When comparing the sub-figures relating to the low discharge and different water surface elevation values, one can see that the shape of the current is slightly different in the westernmost part of the reservoir. Coarse grains settle along the appropriate path. As the current slows down more rapidly for the higher water level, larger particles are deposited closer to each other than for the lower water surface elevation. By contrast, particles that pass that zone and float up to the deeper parts of the reservoir have more space around for further dispersion when the water level is high.

For higher discharge, it is clearly visible that the finer the particle, the further it is carried within the lake. This is true both for both the higher and lower water surface level. However, for the lower level, when the velocities are higher and when the current bends and whirls more, another effect is visible - some medium-sized and fine particles are carried close to the banks and settle there. The larger grains fall closer to the centre of the local bed cross section. This is consistent with the measurements of real grain sizes mentioned in section 3 .

\section{Summary, conclusions and future possibilities}

To sum up the first part of research on the Dobczyce backwater area, it can be said that the process of sediment deposition is intensive there. Sediment material transported by the Raba has been deposited in this area over the years and has continuously changed its character. The whole the region has been generally levelled. Shallow bays and banks with a gentle slope appeared on the southern side. The river channel is close to the northern bank. In that kind of area, almost all the discharge is carried out by the main current and the flow of water in the southern backwater part is extremely slow. Therefore, under the considered conditions, only the smallest particles are able to reach the southern part of the backwater region and settle there. Larger and medium-sized particles settle closer to the main current area; this is visible in both actual sediment samples and in numerical simulations. This leads to the conclusion that the grain size of the deposited material decreases along with the distance from the main current.

The next finding from the sediment sampling is that there is no straightforward dependence between the average grain diameter and the depth of sampling in a given location. Fine and coarse layers seem to lay randomly on one another - this may lead to the conclusion that the process of deposition in the backwater region depends upon the hydrodynamic conditions which become volatile over the course of time in each part of the reservoir (especially during episodes of high discharge). 
The material deposited in the lake is not only made of mineral grains but also of organic matter which is able to store and transport substances in an aquatic environment; this means that biogenic substances or other constituents that pose threats for the good condition of the water reservoir may also be transported. The presence and possible movement of pollution carried by sediment is one of the research areas targeted towards water engineering and water management; conditions favouring the advection of the deposed material and triggering its polluting potential have to be considered.

The obtained results are consistent; the simulation outcome concurs with the results of the in-situ measurements. This indicates that the PTM model may be used to some future more sophisticated simulations regarding transport phenomena in the Dobczyce reservoir. Further research is planned which is aimed especially towards siltation processes and water quality issues.

\section{References}

[1] AQUAVEO, http://www.aquaveo.com/adh, (access: 03.01.2014).

[2] Berger R.C et al., Adaptive hydraulics users manual, AQUAVEO, 2010.

[3] Bojarski A. et al., Wykorzystanie zbiornika Dobczyce w perspektywie krótko i długoterminowej, Kraków, 2012.

[4] Donnell B., et al., Users Gudie RMA2Version 4.5, Valhalla, NY 2009.

[5] Fischer H. B., et al.. Mixing inland and coastal waters, Academic Press, San Diego, CA 1979, 483.

[6] Froelich DC., Two-Dimensional Depth-Averaged Flow and Sediment Transport Model, Federal highway administration, Mc Lean, Virginia 2003.

[7] Gałek M., Analiza czułości modelu FESWMS na zmiennośćjego parametrów na przykładzie Zbiornika Dobczyckiego, Politechnika Krakowska, Kraków 2010.

[8] Gatek M, Hachaj P,. Application of the RMA2/RMA4 Models to Simulate Pollution Transport in a Retention Reservoir, [in:] GeoPlanet: Earth and Planetary Science, Springer-Verlag, ed. P. Rowiński, Berlin Heidelberg 2013, 301-313.

[9] Hachaj P., Numerical modelling of pollution transport phenomena in the lake of Dobczyce, Publications of the Institute of Geophysics. E, Hydrology (formerly Water Resources), Warszawa 2008, 47-54.

[10] Hachaj P. et al., Efektywność modeli hydrodynamicznych w ocenie dynamiki zbiornika zaporowego, Gospodarka Wodna, Warszawa 2014, 286-288.

[11] Hachaj P., Tutro M., Flow patterns for drying and wetting of a retention reservoir bed - numerical modeling, Infrastructure and Ecology of Rural Areas, 4/3, 2014, 1407-1419.

[12] Hachaj, P. Modelling of a two-dimensional velocity field for the water flow in the lake of Dobczyce., [in:] Publs. Inst. Geophys. Pol. Acad. SC. E-7 (401), ed. P. Rowiński, Warszawa 2007.

[13] Hachaj P., Modelowanie pola prędkości wody w zbiorniku dobczyckim - budowa siatki obliczeniowej i wstępne wyniki, Czasopismo Techniczne, 1-Ś/2006.

[14] International Sediment Initiative, Sediment Issues \& Sediment Management in Large River Basins; Interim Case Study Synthesis Report, UNESCO, Beijing 2011. 
[15] Letter J. et al., Users Guide for RMA4 Version 4.5, Valhalla, NY 2008.

[16] Niel J. et al., PTM: Particle Tracking Mode, Coastal and Hydraulics Laboratory, U.S. Army Corps of Engineers, Vicksburg 2006.

[17] Papanicolaou,A., et al., Sediment transportmodeling review - Current and future developments, Journal of Hydraulic Engineering, 134(1), 1-14.

[18] Polski Komitet Normalizacji, Miar i Jakości. PN-86/B-02480 Grunty budowlane. Określenia, symbole, podział i opis gruntów, Warszawa 1986.

[19] RZGW, http://www.krakow.rzgw.gov.pl (access: 11.04.2017).

[20] Shen H. T. et al., A mathematical model for oil slick transport and mixing in rivers, Special Report 93-21. U.S. Army Cold Regions Research and Engineering Laboratory, Hanover, NH 1993. 78.

[21] Soulsby R. L., Dynamics of marine sands - A manual for practical applications, Thomas Telford Publications, London 1997, 249.

[22] Starmacha J., Mazurkiewicz-Boroń G., Zbiornik Dobczycki; ekologia - eutrofizacja - ochrona, Zakład Biologii Wód PAN, Kraków 2000.

[23] U.S Army Corps of Engineers, http://www.usace.army.mil/(access: 07.01.2016).

[24] USSD Committee on Hydraulics of Dams, Modeling Sediment Movement in Reservoirs, USSD, Denver 2015.

[25] van Rijn L. C., Principles of sediment transport in rivers, estuaries and coastal seas, The Aqua Publications, Netherlands 1993.

[26] Witek K., Symulacje przeptywu wody w zbiorniku retencyjnym Tresna za pomoca modelu numerycznego ADH, Politechnika Krakowska, Kraków 2013. 